\title{
CLIMATE CHANGE, DEPLETION OF ENERGY RESOURCES , AND GREENHOUSE EFFECT
}

Cong Thuy Duong, Doan Thu Dung, Phan Thuy Duong, Nguyen Tan Dung, Hoang Thi Hong Chuc, Hoang Thi Linh Chi, Vu Quynh Chi, Nguyen Hoang Chi, Nguyen Cam Duong, Le Thi Thanh Diem.

Vietnam National University, Hanoi Hanoi, December $18^{\text {th }} 2021$.

\section{Preprint DOI: 10.31219/osf.io/w4zec}

Protecting the green - clean - beautiful living environment is a matter of concern for the whole world. There are many global or regional conferences that have been held to discuss and find a way to solve that problem. In which, climate change, energy depletion and greenhouse effect are hot issues, this is one of the biggest challenges facing humanity in the 21 st century because they are directly affecting to ecosystems, environmental resources and human life.

Climate change, with the main manifestation of which is global warming and sea level rise, has created the current extreme weather phenomena. One of the hot facts about this is the forest fires in Greece in August 2021. Greek Prime Minister Kyriakos Mitsotakis described the forest fires in Greece as the biggest ecological disaster the country has faced. The largest fire broke out on the island of Evia (the country's second largest island) from August 3 to August 12, destroying most of the northern part of the island. The fire killed 3 people, and nearly 100,000 hectares of forest and agricultural land were burned [1]. The World Meteorological Organization (WMO) said the bushfires were part of a series of extreme weather events caused by climate change caused by human behaviour. 


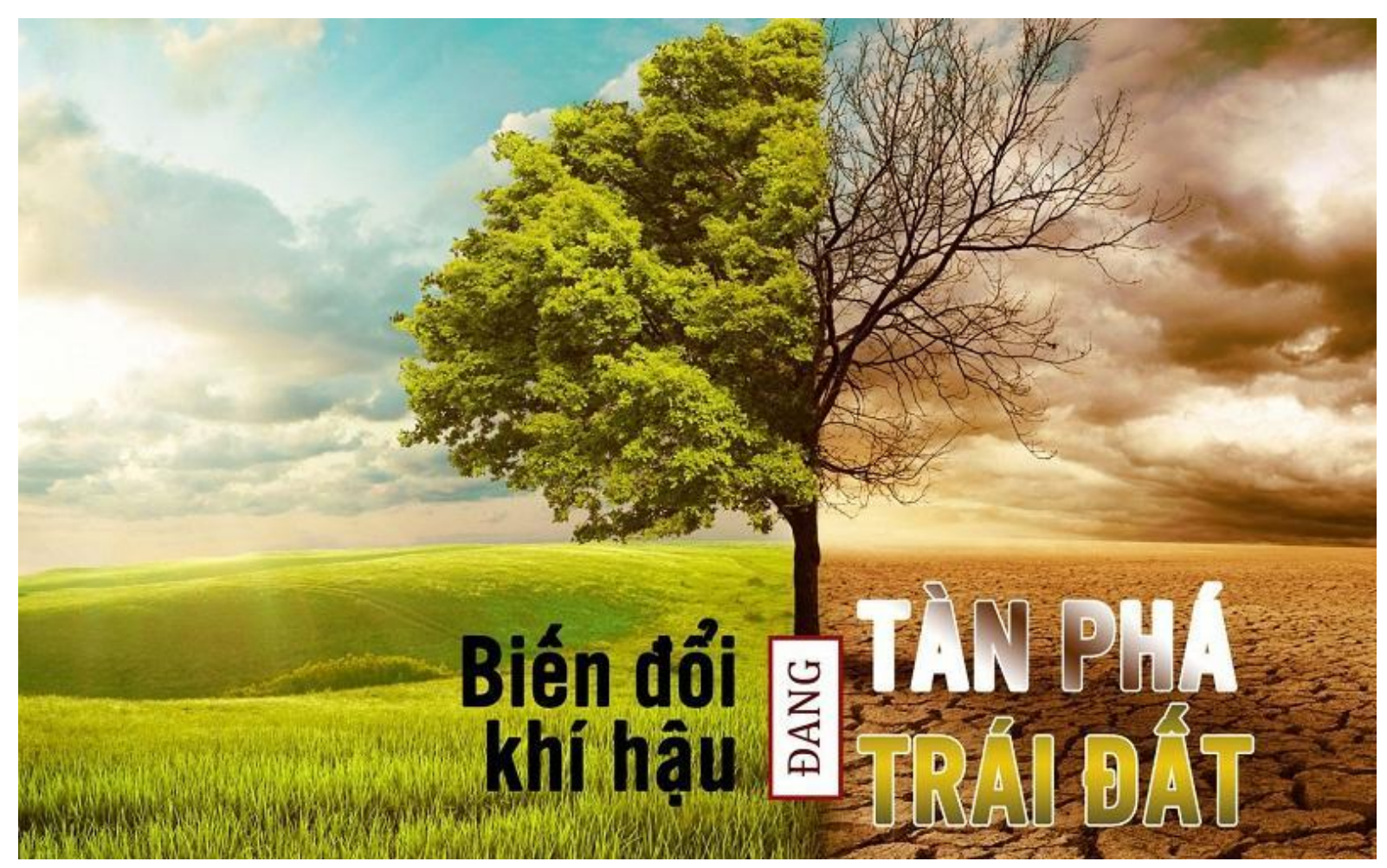

An illustration of how climate change is ravaging the earth

Source: Internet

Besides causing many consequences, climate change also brings many risks to human rights. The impact of climate change is becoming more and more obvious, causing many impacts on people: prolonged natural disasters, droughts and floods leading to crop failure, people lack of food; pollution of soil, water, air... directly affecting human health; subsidence, landslides cause people to lose their homes, even their lives. These things have directly infringed on the human right to life [2].

However, Vietnam and the world are still making efforts to face climate change. During the COP26 conference, Vietnam made many commitments as well as many positive and effective actions to contribute to the fight against climate change on a global scale. Vietnam has also launched action plans and programs to respond to climate change such as the National Strategy on Climate Change, the Implementation Plan of the Paris Agreement on Climate Change, greenhouse gas emission management project, the National Plan to adapt to climate change for the period 2021-2030 with a vision to 2050. Besides, it also legislates climate change response issues such as the law on natural disaster prevention and control, the law on protection environmental protection, law on water resources... [3].

The world also lists 7 efforts in reducing climate change: investing heavily in clean energy; US - China to act against climate change; Africa climate week spurred regional action; COP26 host country "reminds" financial contributors; reform of the global food system; youth action against climate change; pre-COP26 conference.[4] 
Vietnam and the world have been and will always make efforts in mitigating the impact of climate change on human life.

Besides climate change, the depletion of energy is also an issue that needs attention. No longer a warning of a distant future, the depletion of energy resources is gradually being demonstrated by events taking place in reality. An unusually long and cold winter in Europe earlier this year depleted gas reserves, and a series of storms forced the shutdown of refineries in the Gulf. Typically, the economic recovery after the COVID-19 pandemic led to an increase in energy demand.[5] In Vietnam, there is a serious imbalance between electricity development and economic development, stemming from the loss and waste of energy sources, and the low efficiency of electricity use.
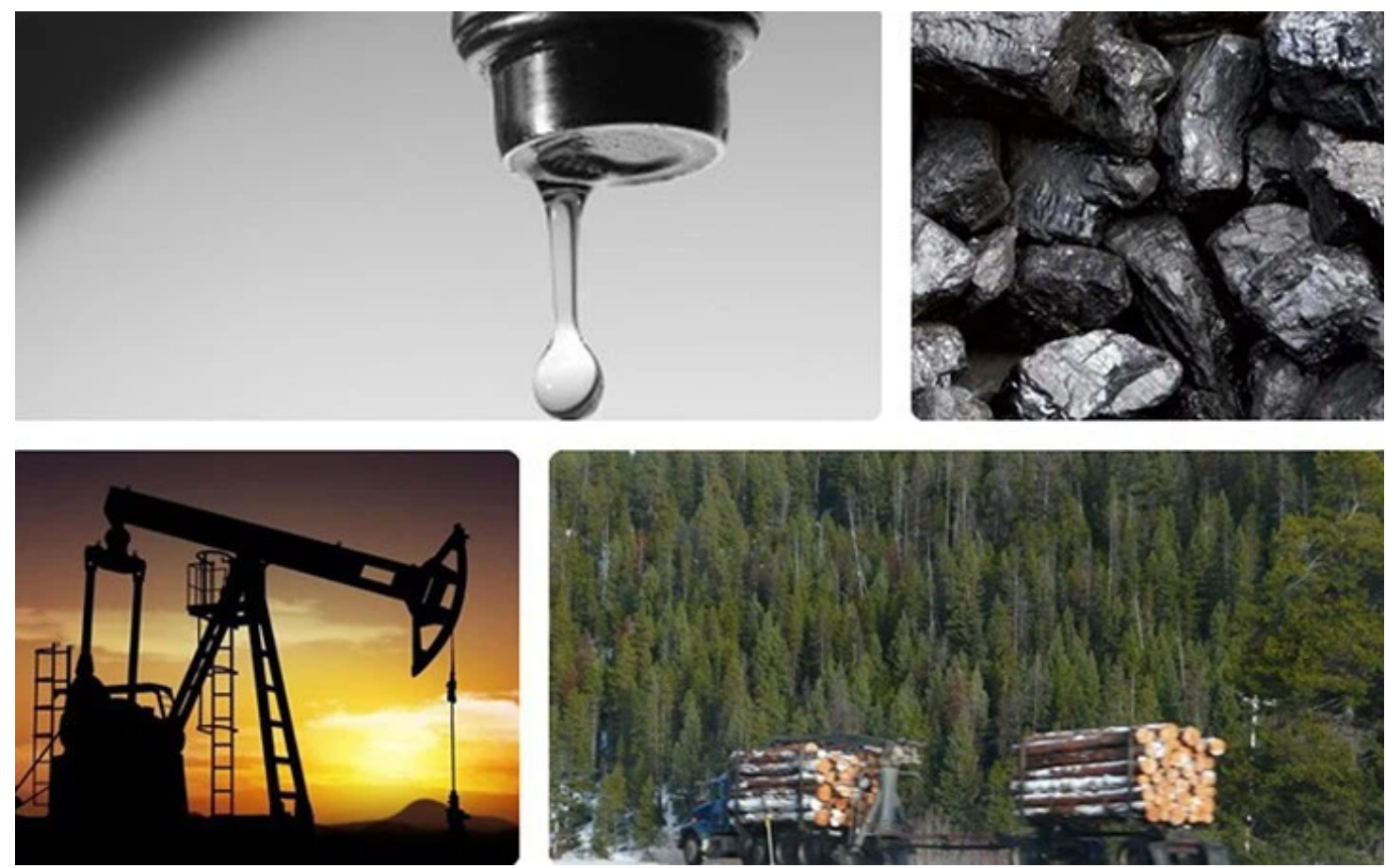

Hình ảnh minh họa cho sụ cạn kiện các nguồn năng lượng trên thế giới Nguồn: Internet

In the 70 s of the last century, to deal with the problem of depletion of fossil energy resources, many countries thought that nuclear energy might be an alternative. However, entering the $80 \mathrm{~s}$, which is only about 10 years later, the world witnessed the failure of this plan. The first reason is that the safety of nuclear power plants is challenged: radioactive leaks, nuclear accidents, radioactive contamination of people,...[6]

However, now we have many reasonable policies to improve the situation. In Vietnam, on February 11, 2020, the Politburo issued Resolution No. 55 - NQ/TW on the orientation of Vietnam's national energy development strategy to 2030, with a vision to 2045. Objective assessment indicates that about 16 million tons of oil 
equivalent (TOE) equivalent to about 103.7 billion $\mathrm{kWh}$ of electricity would have been saved compared to energy demand for socio-economic development if not implemented. This target program. [7] With renewable energy sources, as of July 2020 , on the national power system, there are a total of 99 solar power plants operating with a total capacity of 5,053 MW. There are also 11 wind power plants in operation with a total capacity of $429 \mathrm{MW}$ and $325 \mathrm{MW}$ of biomass and solid waste power of nearly $10 \mathrm{MW}$. Thus, the total capacity of wind and solar power was 5,482 MW, accounting for about $9.5 \%$ of the total installed source capacity of the system. Particularly for rooftop solar power, as of August 31, 2020, there were over 47,000 systems installed with a total capacity of $1,128 \mathrm{MWp}$ [8]

In the world, there has been a push to use renewable energy sources. In West Africa, Côte d'Ivoire produces about 2,000 MW of electricity per year, of which thermal power accounts for $75 \%$, and the rest is hydroelectric. Kuwait aims to increase the share of renewable energy to $11 \%$ of total electricity by 2020 and to $16 \%$ by 2030.[9]In addition, we must include the Alliance Summit. Europe on energy issues. The European Union has urged countries to urgently use "toolboxes" to provide short-term support to the most vulnerable consumers as well as European companies. [10]

In addition to the above two problems, the greenhouse effect is also an equally hot issue. The greenhouse effect is one of the main causes of global climate change. As greenhouse gas concentrations increase, so does the average global surface temperature. And that has contributed to extreme weather events around the world. (In the South American continent, severe drought has affected many places in 2020, especially northern Argentina, Paraguay... Or the North Atlantic region has had an unusually intense rainy season, with 30 tropical cyclones, breaking the record for the rainy season of 2005) [11]. Rising global temperatures also lead to the melting of Greenland, Antarctica and glaciers around the world and cause sea levels to rise. Globally, sea levels have risen on average $3.29(+/-0.3) \mathrm{mm}$ per year, and peaked in 2020. [12] 


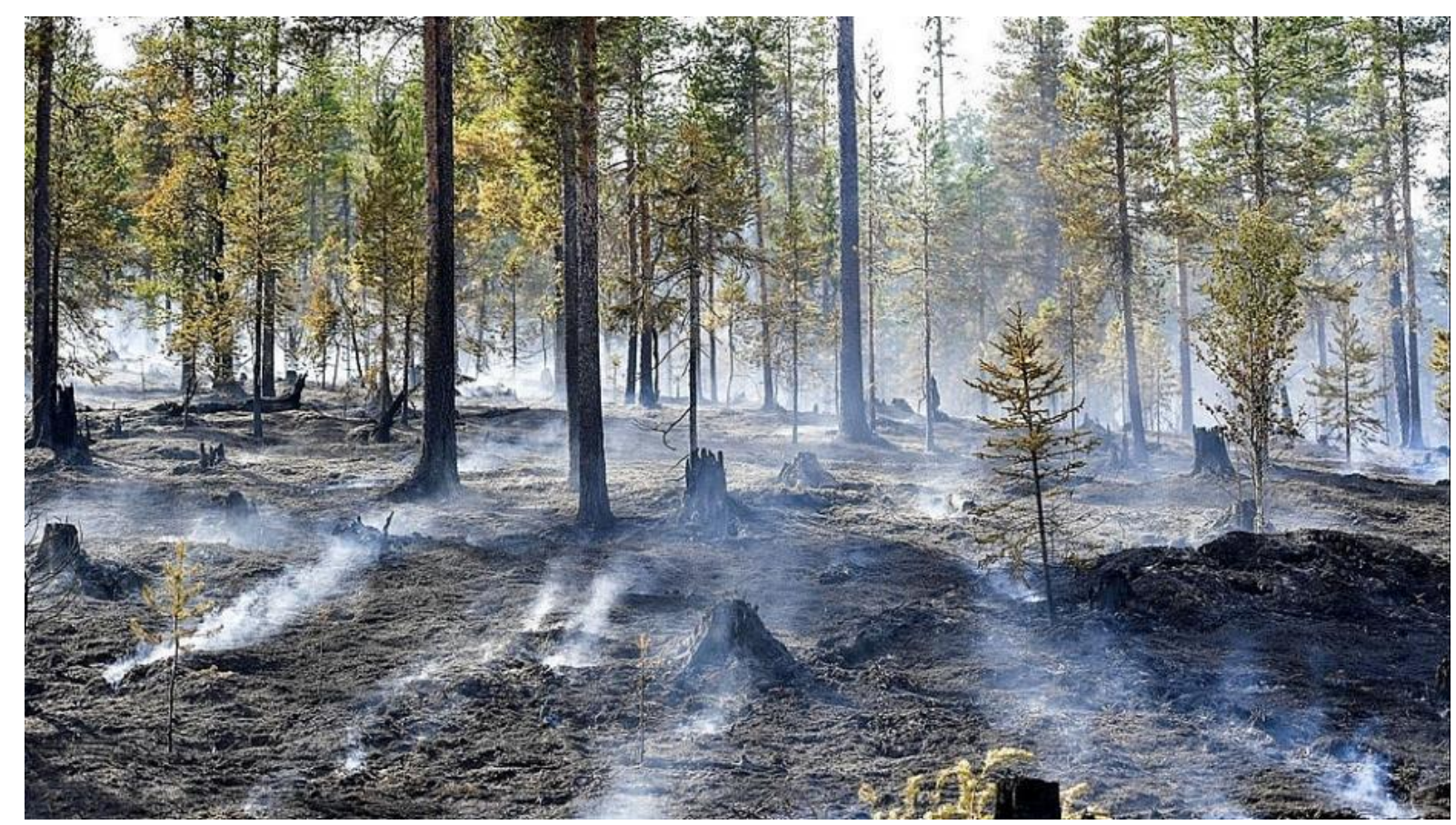

Illustration for the depletion of energy resources in the world

Source: Internet

In response to the increasingly alarming state of the greenhouse effect, environmental organizations actively participate in conferences to come up with agreements and solutions to improve this climate phenomenon. However, many of those efforts have failed. The goal of keeping the Earth\&\#39;s temperature from rising more than $1.5^{\circ} \mathrm{C}$, which has been set by the parties to the Paris Agreement, has been realized. As the sixth report (AR6) of the Intergovernmental Panel on Climate Change (IPCC) highlighted: " Some changes, such as rising sea levels, are irreversible for hundreds or thousands of years.\&quot;Climate and energy experts from Sweden, Norway and Austria drew the conclusion that, to achieve the goal of keeping the Earth\&\#39;s temperature from rising more than $1.5^{\circ} \mathrm{C}$, energy consumption would need to fall by an unprecedentedly large amount, which no other economy in the world can afford. [13]

The greenhouse effect increases existing risks and exacerbates factors that can lead to conflict and insecurity. In Sudan, for example, the influence of the greenhouse effect on agriculture and pastoralism with ethnic political factors contributed to the escalation of violence in Darfur and made conflicts more difficult to resolve. In Syria and Iraq, the radical organization Daesh exploits the growing competition for weaponized water and natural resources by controlling access to and diversion of rivers. In Central America and the Caribbean, devastation caused by extreme weather 
events has devastated critical infrastructure and displaced populations, and in some places, has been linked to a spike in crime rates. [14]

Internationally, the United Nations has made many efforts in the fight against the greenhouse effect. The key results were the United Nations Framework Convention on Climate Change (UNFCCC) - which entered into force on 19 March 1994 with the objective of achieving stabilization of greenhouse gases in the atmosphere at a level that would prevent Dangerous human intervention in the climate system, the Kyoto Protocol (KP) - entered into force on 16 December 2005 with the primary objective of assisting developing countries in realizing sustainable development and developed countries make commitments to reduce greenhouse gas emissions.[15]Being well aware of the impact of the greenhouse effect, Vietnam has soon participated in regional and international response activities on greenhouse effect as well as climate change such as: Joining the signing of the United Nations Framework Convention on Climate Change. (UNFCCC); signed the Kyoto Protocol (KP); passed the Law on Economical and Efficient Use of Energy...; implementing programs and projects directly related to greenhouse gas emission reduction: National target program on economical and efficient use of energy; national program on mitigation of greenhouse gas emissions through efforts to limit deforestation and forest degradation, sustainable management of forest resources,...[16]

In short, climate change, energy depletion, and the greenhouse effect are threatening the environment as well as human life. Therefore, each of us needs to raise awareness and propagate to be able to deal with the above problems, bringing back the inherent green, clean and beautiful environment of the environment.

\section{REFERENCES:}

[1] T. Huong, "Hy Lạp đã khống chế được các đám cháy rừng kéo dài 9 ngày qua," Báo Tin Túc, 2021.

https://baotintuc.vn/the-gioi/hy-lap-da-khong-che-duoc-cac-dam-chay-rung-keodai-9-ngay-qua-20210812103847052.htm.

[2] Á. Huyền, "Đảm bảo quyền con người trước tác động của biến đổi khí hậu," VOV, 2016.

https://vovworld.vn/vi-VN/binh-luan/dam-bao-quyen-con-nguoi-truoc-tac-dongcua-bien-doi-khi-hau-447287.vov.

[3] N. Nhâm, "Việt Nam tham gia tích cực, trách nhiệm chống biến đổi khí hậu," Báo điện tủ Đảng Cộng Sản Việt Nam, 2021, https://dangcongsan.vn/the-gioi/nhung-van-de-toan-cau/viet-nam-tham-gia-tichcuc-trach-nhiem-chong-bien-doi-khi-hau-596974.html.

[4] H. Thanh, "7 nỗ lực chống biến đổi khí hậu nổi bật trước thềm Hội nghị COP26," Báo Tin Túc, 2021. 
https://baotintuc.vn/the-gioi/7-no-luc-chong-bien-doi-khi-hau-noi-bat-truoc-the m-hoi-nghi-cop26-20211011155850756.htm.

[5] B. Anh, "Thế giới đói năng lượng," Tuổi trẻ online, 2021. https://tuoitre.vn/the-gioi-doi-nang-luong-20211012084245602.htm (accessed Dec. 15, 2021).

[6] G. T. M. T. và T. tâm C. nghệ H. Học, "Năng lượng từ hyđrô sẽ thay thế dầu khí, nguyên tử," Báo Nhân Dân, 2007.

https://nhandan.vn/khoa-hoc/nang-luong-tu-hydro-se-thay-the-dau-khi-nguyen-t u-434949 (accessed Dec. 15, 2021).

[7] A. Bình, "Sử dụng tiết kiệm năng lượng và hiệu quả là nền tảng cho phát triển bền vững," Bộ Công Thuơng Việt Nam, 2021.

https://moit.gov.vn/tin-tuc/su-dung-nang-luong-tiet-kiem-va-hieu-qua/su-dung-ti et-kiem-nang-luong-va-hieu-qua-la-nen-tang-cho-phat-trien-ben-vung.html.

[8] G. Hưng, "Khai thác, sử dụng hiệu quả các nguồn năng lượng tái tạo," Báo điện tử Đảng Công Sản Việt Nam, 2020.

https://dangcongsan.vn/khoa-hoc-va-cong-nghe-voi-su-nghiep-cong-nghiep-hoahien-dai-hoa-dat-nuoc/diem-nhan-khoa-hoc-va-cong-nghe/khai-thac-su-dung-hi eu-qua-cac-nguon-nang-luong-tai-tao-564429.html (accessed Dec. 15, 2021).

[9] M. Anh, "Đẩy mạnh sử dụng các nguồn năng lượng tái tạo," Báo Nhân Dân, 2019.

https://nhandan.vn/tin-tuc-the-gioi/ay-manh-su-dung-cac-nguon-nang-luong-tai-t ao-348461/ (accessed Dec. 15, 2021).

[10] T. Quyên, "Hội nghị thượng đỉnh Liên minh châu Âu 'nóng' với vấn đề năng lượng," Vietnam Plus, 2021.

https://www.vietnamplus.vn/hoi-nghi-thuong-dinh-lien-minh-chau-au-nong-voivan-de-nang-luong/748308.vnp.

[11] DWRM, "Năm 2020 trở thành một trong ba năm nóng nhất từng được ghi nhận trên Trái Đất," Bộ Tài nguyên và Môi trường, 2020.

http://dwrm.gov.vn/index.php?language=vi\&nv=news\&op=Nhin-ra-The-gioi/Na m-2020-tro-thanh-mot-trong-ba-nam-nong-nhat-tung-duoc-ghi-nhan-tren-Trai-D at-9600

[12] N. R. Claire Ransom, Valentine Haran, "The State of the Global Climate 2020," World Meteorological Organization, 2020.

https://public.wmo.int/en/our-mandate/climate/wmo-statement-state-of-global-c limate

[13] “Thất bại trong việc đối phó với biến đổi khí hậu: Thảm họa không thể tránh khỏi trên Trái đất," Sputnik Việt Nam, 2021. 
https://vn.sputniknews.com/20211101/that-bai-trong-viec-doi-pho-voi-bien-doikhi-hau-tham-hoa-khong-the-tranh-khoi-tren-trai-dat-12329804.html

[14] R. DiCarlo, "Climate change multiplying factors that lead to insecurity for millions, Rosemary DiCarlo tells 'Arria Formula' meeting," Political and Peacebuilding Affairs, 2020.

https://dppa.un.org/en/climate-change-multiplying-factors-lead-to-insecurity-mil lions-rosemary-dicarlo-tells-arria-formula.

[15] Tài liệu hướng dẫn dạy và học về UÚng phó với biển đổi khí hậu. Bộ Giáo dục và Đào tạo.

[16] “Đóng góp do quốc gia tự quyết định của Việt Nam,” 2020. 